3. Знание теории литературы способствует пониманию и восприятию природы произведения.

4. Следует помнить, что только после прочтения и разбора произведения можно вступить в этап по изучению теории литературы, чтобы достичь ожидаемых результатов. Ученик не только узнает о теории литературы, но и знакомится с индивидуальным творческим почерком писателя, с его идеостилем.

Список литературы:

1. Беленький Г.И. Теория литературы в средней школе. Пособие для учителя. М., «Просвещение», 1976, 222с.

2. Беленький Г.И., Снежневская М.А. Изучение теории литературы в средней школе (4-10 классы): Пособие для учителя. - М.: Просвещение, 1983. - 256 с. - (Б-ка учителя лит.).

3. Богданова О.Ю. и др. Методика преподавания литературы: Учебник для студ. пед. вузов / О.Ю.Богданова, С.А.Леонов, В.Ф.Чертов; Под ред. О.Ю.Богдановой. - М.: Издательский центр «Академия», 1999. - 400 с.

4. Голубков В.В. Методика преподавания литературы. - Москва: Учпедгиз, 1962. -489 c.

5. Рыбникова М.А. Очерки по методике литературного чтения: Пособие для учителя. - 4-е изд., испр.-М.: Просвещение, 1985. - 288с. - (Б-ка учителя лит.).

6. Саха литературатын оскуолақа үөрэтии методиката: Учууталга кинигэ / Саха Өрөсп. төрүт омуктар оскуолаларын чинчийэр ин-т; [эпп.ред. Е.М.Поликарпова]. Дьокуускай: Бичик, 2006. - 288c. (Саха оскуолатын учууталыгар көмө).

7. Снежневская М.А. Теория литературы в 4-6 классах средней школы. Пособие для учителей. М., «Просвещение», 1978, 176с.

8. Филиппова Н.И. Төрөөбүт литератураны 4-7 кылаастарга үөрэтии. Якутскай: Кинигэ изд-вота, 1985. - 144 с.

9. Филиппова Н.И. Төрөөбүт литератураны кылаас таһынан аақыы методиката. Саха оскуолатын 5-9 кылаастарыгар. Учууталга пособие: - Якутскай: Кинигэ изд-вота, 1991. - 72c.

\title{
Процесс адаптации молодого педагога на новом рабочем месте
}

\section{Прядезникова А.А., студентка, Северо-Восточный федеральный университет, 2. Якутск E-mail: AilitaVinokurova@mail.ru}

Научный руководитель: к.психол.н., доцент Михалева А.Б.

В настоящее время в школах большую часть учителей составляют педагоги в возрасте. Тут стает проблема омоложения педагогического коллектива. В начале учебного года в школу приходят молодые специалисты, которые только что окончившие учебное заведение. Молодые педагоги сталкиваются с проблемой адаптации на новом рабочем месте. Начинающий учитель при работе в школе теряется. Полученные знания 
в вузе, обычно достаточно, но молодым учителям, несомненно, не хватает опыта работы. Слабая методическая подготовка, недостаточное владение приемами и методом обучения вызывает определенные трудности у начинающего педагога. Чтобы начинающий учитель не оставался наедине с проблемами, ему нужна помощь со стороны администрации школы.

Период вступление в профессиональную деятельность называют профессиональной адаптацией. «Это процесс вхождения личности в новое социальное окружение с целью совместной деятельности в направлении прогрессивного изменения, как личности, так и среды» [1. стр. 127].

Выдвигают ряд аспектов адаптации работника к новой среде:

- Организационный - усвоение сотрудником роли педагога в общей организационной структуре школы, особенностей управления школой, привыкание к новым условиям трудовой деятельности: нормативно-правовым, социальноэкономическим, морально-психологическим, организационно-управленческим;

- Психофизиологический - приспособление к физическим и психологическим нагрузкам педагога, его физиологическим условиям труда;

- Профессиональный - освоение молодым педагогом всех видов деятельности учителя в соответствии с должностными обязанностями этическими нормами, доведение основных показателей деятельности учителя до необходимого уровня;

- Социально-психологический - приспособление к относительно новому социуму, нормам поведения и взаимоотношениям в педагогическом коллективе, принятие единых педагогических требований. [1. стр. 129]

Для адаптации начинающего учителя нужна помощь в первую очередь от директора школы, заместителя директора школы и педагога-наставника. Состоит эта работа из двух этапов: общего и индивидуального.

В первом этапе (общий этап) предполагается, что у начинающего учителя должна формироваться целостное представление о школе. Несомненно, в этот этап директор школы в первую неделю работы молодого педагога, должен ознакомить: 1) о размере заработной платы; 2) режиме трудового дня; 3) дополнительных льготах; 4) технику безопасности и охране труда; 5) дисциплинах; 6) правиле внутреннего распорядка. Далее директор школы знакомит со школой: историей, нормами, традициями, педагогическим коллективом, учениками. Затем заместитель директора знакомит молодого учителя с его учебным кабинетом. Параллельно на этом этапе заместитель директора и директор школы проводят ориентационное собеседование. Собеседование производит оценку профессионального уровня молодого учителя, определяется круг задач, объясняется требования к работе педагога, должностные инструкции. Так же директором и заместителем назначается наставник - педагог.

Во-втором этапе (индивидуальный этап) продолжается процесс адаптации, то. есть около одного года. Индивидуальный этап включает в себя более детально ознакомиться со школой и ее деятельностью. Начинающий педагог в процессе работы налаживает отношения с коллегами по работе. Кроме этого, молодой учитель получает необходимые навыки для педагога. Наставник - педагог должен выявлять психологические трудности, появляющийся в процессе адаптации при выполнении отдельных видов деятельности, способствовать в их благополучном разрешении.

Психологи, в качестве фундаментальных стратегий поведения молодого учителя выделяют два: пассивная и активная. «Для пассивной стратегии характерно подчинение личности интересам и требованиям среды. Люди не уверены в своей профессиональной 
компетентности, не готовы к изменению сложившегося образа жизни. Люди не уверены в своей профессиональной компетентности, не готовы к изменению сложившегося образа жизни. Не редко кризисная ситуация вызывает у них ухудшение самочувствия, заставляя тем самым уйти от решения проблем. Они не предпринимают каких-либо активных действий, полагаясь на помощь со стороны других или ориентируют свою активность (в какой-то мере это конструктивно) на другие сферы - семью, хобби». [2. стр.124]. В этом случае учитель переживает дискомфорт и неудовлетворенность процессом, ему необходима особая поддержка и стимулирование педагогической деятельности, так как выбор данной стратегии может быть обусловлен различными факторами. Анализ этих факторов задача руководства. Это может быть следствием неблагожелательности педагогического коллектива, трудности самого человека (сложности индивидуальных особенностей), высокая цена усилий несопоставимая с отдачей и т.д.

Понемногу преодолеваются межличностные и педагогические проблемы. Молодой учитель «притирается» к коллективу, приступает устойчиво работать. В завершении первого года работы директор школы, заместитель директора и педагог - наставник принимают решение о завершении адаптации и начале самостоятельной работы учителя. Нельзя полагаться на годовую цикличность работы учителя. Процесс адаптации начинающего учителя может затянуться до 1,5 - 2,5 лет. [3. стр.9]

Процесс адаптации можно считать законченным, если:

- работа не вызывает у учителя чувства напряжения, страха неуверенности, стала привычной для него;

• он овладел необходимым объемом знаний и навыков;

- поведение новичка отвечает требованиям его должности и администрации;

• у учителя выражено желание совершенствоваться в профессии;

• он чувствует удовлетворенность выполняемой работой;

- пользуется уважением учеников.

С целью диагностики и прогнозирования возможных проблем адаптации студентов, будущих учителей средних школ, определили их педагогическую способность. В опросе приняли участие 59 студентов старших курсов СВФУ, обучающихся педагогической профессии по профилю география и экология, физика и информатика, химия и биология.

Таблица 1

Результаты методики «Педагогические ситуации»

\begin{tabular}{|c|c|c|c|}
\hline Профиль & $\begin{array}{c}\text { выше 4,5 балла } \\
\text { высокий уровень }\end{array}$ & $\begin{array}{c}\text { 3,5-4,4 балла } \\
\text { средний уровень }\end{array}$ & $\begin{array}{c}\text { меньше 3,4 балла } \\
\text { низкий уровень }\end{array}$ \\
\hline $\begin{array}{c}\text { География и } \\
\text { экология }\end{array}$ & 7 & 14 & - \\
\hline $\begin{array}{c}\text { Физика и } \\
\text { информатика }\end{array}$ & 4 & 14 & - \\
\hline Химия и биология & 7 & 12 & - \\
\hline
\end{tabular}

Согласно результатам исследования, все студенты в высокой (31\%) и средней степени (79\%) показали наличие способностей к педагогической профессии (рис. 1). Низкий уровень или слаборазвитые педагогические способности не проявились. Вместе с тем преподавателям психолого-педагогического цикла рекомендуем продолжить 
развитие способностей студентов со средним уровнем, в частности будущих учителей физики и информатики.

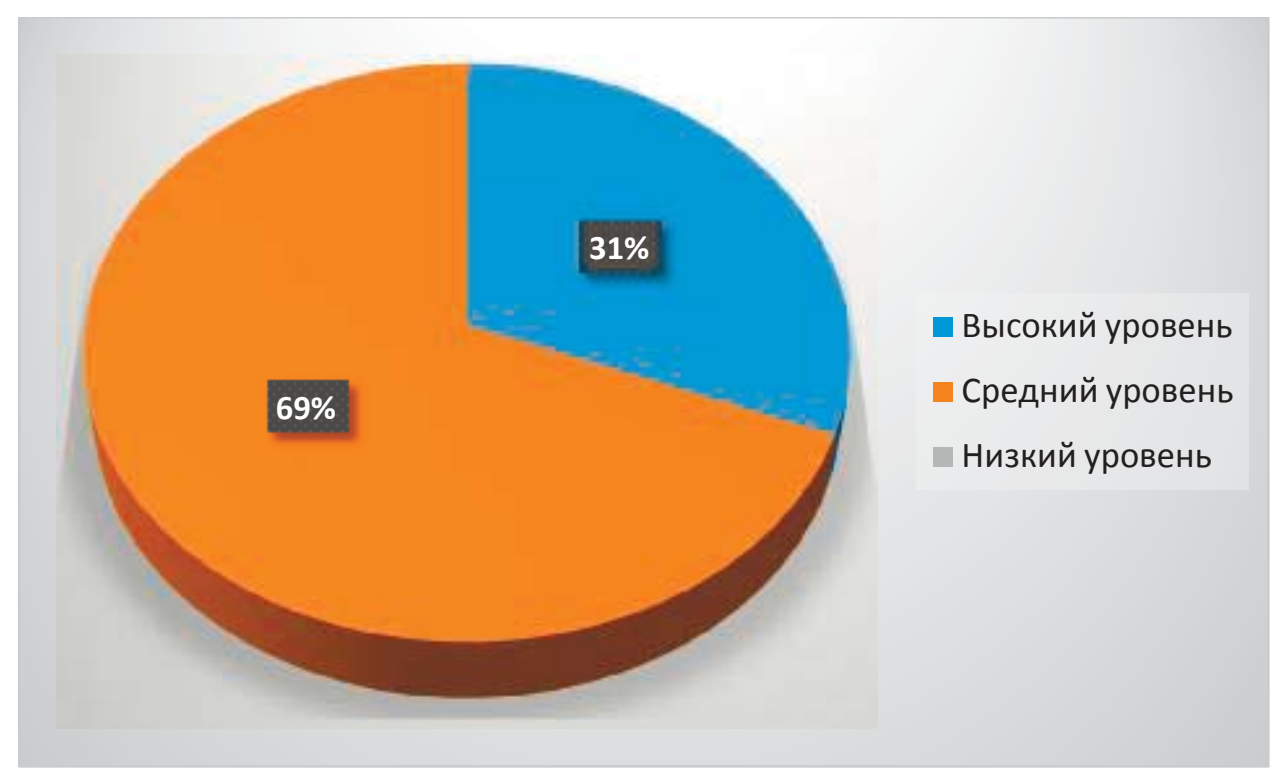

Рис. 1. Общая сумма баллов

В заключение обозначим, что адаптация молодого учителя, во многом определяется педагогическими способностями его самого, считается завершенной в случае соответствия его деятельности цели учебного заведения и требованиям занимаемой должности. Работа не вызывает чувств напряжения, страха и неуверенности, а показатели академической успеваемости обучающихся соответствуют установленным нормативам. У педагога должно быть выражено желание совершенствоваться в профессии, с которой связано его будущее; чувствует удовлетворенность выполняемой работой и считает оценку своего трудового вклада справедливой; пользуется уважением и любовью учеников.

\section{Список литературы:}

1. Щербаков А.С. Профессиональная адаптация начинающего педагога на рабочем месте// Народное образование. № 6, 2009. С. 127-133

2. Котова С.А. Адаптация в должности и освоение профессии учителя// Народное образование. № 8, 2010, с.124-125.

3. Михалева А.Б., Прядезникова А.А. Адаптация молодого учителя// Мир науки и инноваций. №1 (1), том 8, - Иваново: Научный мир, 2015 - 86 с. 